Dr MP Jama

University of the Free State

DOI: $h$ ttp://dx.doi.

org/10.18820/2519593X/pie.

v35i1.3

ISSN 0258-2236

e-ISSN 2519-593X

Perspectives in Education

2017 35(1): 28-39

(C) UVIUFS

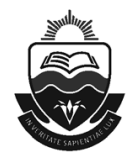

\section{Applying a humanistic pedagogy to advance and integrate humane values in a medical school environment}

\begin{abstract}
Sometimes universities in general are criticised because of impersonal campus environments, or "academic incivility". However, research shows that this phenomenon is more common in medical schools, pointing to increased levels of stress and incidences of attempted suicide among medical students. The decay in humanitarian attitudes and decline in humane values contribute to stress, although some academics believe that this type of environment is normal for medical students. To confront this criticism, academics should not only focus on cognitive aspects, but also adopt a humanistic pedagogy by integrating humane values in curricular and co-curricular activities of the academic environment. The aim of this paper is to illustrate how a humanistic pedagogy is applied in a Medical School in South Africa, by sharing narratives collected from medical teachers who advance and integrate humane values such as, care, empathy and love in their teaching practice.
\end{abstract}

Keywords: medical education; humane values; humanistic pedagogy; narrative; care; empathy; love.

\section{Background and context}

The University of the Free State (UFS) in Bloemfontein, South Africa (SA), endeavours to be recognised as an excellent institution in two of its performance areas, namely (i) the academic project, which focuses on excellence in teaching, learning and research, and (ii) the human project, with its focus on reconciliation and social justice (UFS Integrated Report, 2013). This paper is situated within the human project, which is located mainly in the Institute for Reconciliation and Social Justice (IRSJ) at the UFS. The aim of the IRSJ is to "cultivate humanity as a counterstrategy to the disrespect and violence that pervade human relations and erode human dignity" (IRSJ, 2013).

In particular, this paper focuses on the School of Medicine (SoM) at the UFS and is based on my 15 years of experience as a lecturer, student academic support and development practitioner, tutor programme coordinator in the in the SoM, researcher in the field of higher and medical education and head of one of the student residences at the UFS. Within the different roles and responsibilities in these positions, I have the opportunity to interact and engage 
with students from diverse backgrounds. During these interactions and engagements, I have gained rich information on the many challenges that students face in academic environments. In addition, being from a similar social and school background as some of the students, I have realised the significance of adopting a humanistic pedagogy to advance and integrate humane values in a medical school environment, which is sometimes perceived as being inhumane.

\section{Introduction}

There are studies that have reported on dehumanising campus environments and the effects on students (Chickering \& Gamson, 1987; Wilcox \& Ebbs, 1992; Condren et al., 2002; Peréz et al., 2010). Notably, the study by Thomas (2002) reveals that the relationship between students and teachers is fundamental for learning and coping with academic difficulties. Rovai, Gallien and Wighting (2005) concur that students learn from teachers who display humane values such as friendliness, warmth and kindness, and those who foster a close professional relationship with students. In SA, a study by Jansen, Tabane and Sehlapelo (2010) describes the persistence of apartheid's practices, with negative attitudes and racist expressions being made towards black students, thus portraying the hostility of the academic environment; hence, the significance of fostering humane values in the academic environment.

Relatedly, Palmer and Zajonc (2010) use Wendell Berry's statement:

the thing being made in a university is humanity.... what universities...are mandated to make or to help to make is human beings in the fullest sense of those words - not just trained workers or knowledgeable citizens but responsible heirs and members of human culture... Underlying the idea of a university - the bringing together, the combining into one, of all disciplines - is the idea that good work and good citizens are the inevitable byproducts of the making of a good - that is, a fully developed - human being.

Although the studies referred to point to issues around the general higher education environment, some studies have focused on the medical environment (Rosenberg, 1971; Edward \& Zimet, 1976), with Whitman, Spendlove and Clarke (1984) pointing to what is called "academic hardliners" and "academic elitists". Relatedly, Cohen (2002) refers to issues in the explicit curriculum (caring, compassion, empathy, respect, fidelity, the need to be trustworthy, honest and committed) and in the hidden curriculum, in which students experience opposite values, learning environments that "revere objectivity, detachment, wariness and distrust of emotions" and the "tarnished reputation and dehumanising demands" on students. Other studies (Derby, Thomas \& Shanafeld, 2006; Hojat et al., 2009; Gaufberg et al., 2010; Veerapen \& McAleer, 2010) refer to cynism, decay in humanitarian attitudes, decline and erosion of empathy that "fades away like an endangered species", leading to stress among medical students (Hojat et al., 2009). In particular, Roberts (2010) claims that contrary to expectation, many of the experiences in medical school may overwhelm and exhaust instead of inspire students.

Clark (2008) describes incidences in which students experience "academic incivility", meaning any "speech or action in the form of a rude or sarcastic comment disrupting the harmony of the teaching-learning environment". In my PhD study in Higher Education (MoagiJama, 2009), one medical student wrote, "this faculty has lost the art of humanity", thus affirming claims of an inhumane medical environment. Moreover, during my interaction with students, they refer to remarks such as "what type of doctor are you going to be" and "I hope 
you will not be my doctor one day" made in the presence of peers and patients, and how these remarks humiliate and lower their self-esteem.

Findings from the studies mentioned above suggest that there is a need to explore the humanistic domain of the academic environment in medical schools. Fortunately, this area of humanistic research is gaining prominence in different countries. For instance, in the United Kingdom (UK), the purpose of the strategic map of the Faculty of Education at Liverpool Hope University is to "contribute to the development of knowledge and understanding in all fields of education characterizing all the work with values arising from hope and love" (Liverpool Hope University, 2010). Lovat et al. (2011) refer to the National Framework for Values Education (NFVE) in Australian schools as a way to address some of the social, emotional, moral, spiritual and aesthetic developmental issues that schools tend to neglect. Relatedly, Veugelers (2011) states that currently, there is an interest in the role of education on values and norms in the post-modern world. In addition, Kleijnen et al. (2009) maintain that values are reflected in mission statements and branding slogans of institutions and organisations, and how these portray powerful and stable forces that influence their performance and success. Regrettably, these are not given serious consideration in practice (Harland \& Pickering, 2011).

Lyons (2006) posits that one of the primary values of social sciences is opening up to studying the richness of human experiences. However, the challenge of humanistic research is teaching people how to trust their capacity to recognise choices they could make to function optimally, thus "finding their calling". As a researcher in the field of higher and medical education, one of the choices that I made was to explore the humanistic domain of medical education by collecting narratives of lecturers who apply a humanistic pedagogy to advance and integrate humane values in their teaching practice in the SoM at UFS.

\section{A humanistic pedagogy}

DeCavalho (1991) stated that as a paradigm, humanism evolved in the 1960s from the work of Abraham Maslow and Carl Rodgers and became a movement in American psychology, with the crisis in American education continuing because of the failure to introduce Maslow and Rodgers' humanistic dimension in the education system. Salazar (2013) refers to a humanisation of the academic environment and Freire's notion of the humanistic teacher. According to Salazar (2013:127), in his writings, Freire "grapples with the meaning of human existence and the purpose of pedagogy" and envisaged a humanising pedagogy. Hence, the concept "humanising pedagogy" is regarded as Freire's original contribution. Salazar further states that in Freire's 1990 Pedagogy of the Oppressed, he describes a humanising pedagogy as a revolutionary approach in which the teacher does not manipulate the student, but expresses the consciousness of the student. Relatedly, Bartolomé (1994) wrote about a dehumanising pedagogy as a deficit approach that strips off the students' cultural, linguistic and familial aspects. Relatedly, Biesta (1998) referred to a "pedagogy without humanism".

In addition, a humanistic pedagogy can be related to a humanistic learning theory that Ozuah (2013) posits is based on the assumption that people have a natural tendency to learn and learning will flourish in a nourishing and encouraging environment. Salazar (2013:127) also writes about mechanical pedagogical approaches that devalue and dehumanise teachers and students, urging teachers to "engage in quest for mutual humanization".

Linking to the above, Freire made a call for educators to reinvent the pedagogical humanistic philosophy in their own context. Educators are responsible for promoting a 
more fully developed human world through their pedagogical principles and practices (Salazar, 2013). Hence, the three narratives collected from the teachers in the SoM at UFS reported in this article epitomise Freire's and Salazar's call for reinvention of the humanistic pedagogy and integration of such principles and practices. These narratives form part of a research project that focuses on the academic support and development of undergraduate medical students at UFS.

The representation of the narratives follows a narrative research and inquiry, which according to Clandinin, Pushor and Murray Orr (2007:21) is "appealing to teachers and educators as they provide comfort associated with telling and listening to stories as well as inquiries into our own practices". In their work, Connelly and Clandinin (1990:2) asserted that "by nature people live their storied lives and tell stories of those lives". Hence narrative researchers study stories that they collect from others and write narratives of experience (Connelly \& Clandinin, 1990; Polkinghorne, 2007). These researchers situate these stories within the participants' personal experiences (their job, homes), cultural (racial or ethnic) and historical (time and place) and context (Creswell et al., 2007). Thus, the narratives reported in this article describe the stories of the lives of the medical teachers and ways they model a humanistic pedagogy in their practice. These narratives were captured on audio and video recording with their permission. In relating their stories, the teachers provided their personal experiences and background in their jobs as teachers as well as at home (as husbands and parents). They also relate these experiences to specific times and places. In the following representation of narratives that epitomise the values (i) care, (ii) empathy and (iii) love, the teachers will be identified as $\operatorname{Dr} A, \operatorname{Dr} B$ and $\operatorname{Dr} C$. The basis for the analysis of these narratives was literature on these three values.

\subsection{The care narrative}

Some studies reporting on care in the academic environment purport that a caring relationship between a teacher and a student can influence affective and cognitive learning in a positive way (Teven \& McCroskey, 1997; Doyle \& Doyle, 2003; Kim \& Schallert, 2011). Noddings (2010a:147) states that, "We do not 'care' in order to model caring; we model care by caring". The following narrative by $\operatorname{Dr} A$ epitomises this statement.

Dr A started with a background about his life as a child, husband and parent. He described how as a child he moved from one country to another with his parents, how he was once "dumped and deposited in a super negative environment" and was labelled a racist because he was from South Africa (SA). He even said, "I faced dark moments in my life". When he came back to SA, he met some Christian colleagues and students. Notably DrA said that it was important to understand the background because "this is who I am...nothing of what happened in the course of my life could have occurred if I did not experience these specific incidents".

Dr A's story on care was about how he and his family had to stay with three students, which was "a way God used us and was a season in our lives". In the case of the first student, he received a phone call from a father who suspected that his child was depressed, suicidal and contemplating to discontinue his studies. Dr A said "without any hesitation we just knew we had to take him". In the second case, he received a phone message from a student one Saturday morning stating... "Prof, I am cold, hungry, writing examinations on Monday, have been walking in the mall for the past two days". Once again the family "just knew he had to come" and stay with them. The challenge was having an additional person, young children and the first student. They prayed to God to provide space for this student. Their prayer was 
answered when a woman who was renting one of the rooms suddenly gave 24 hours' notice to leave. Eventually the first student completed his studies and left. Later on they met the third student during an outreach camp and again because of his circumstances they "looked at each other and knew we had to take him", thus having two students living with them again. Eventually the students completed their studies and left.

According to $\operatorname{Dr} A$, all three these students came from dysfunctional families and for the first time experienced a normal family environment consisting of both parents, thus changing their perspective on fatherhood and marriage. According to him, their relationship with the students was strengthened because they shared the same worldviews and values. Moreover, the three students had the "humility to become children" and even called them mom and dad, and their children regarded them as their siblings.

Responding to calls for help affirms Noddings' (2010b:12) view that "when people attend and receive expressions of pain or need, they feel drawn to that pain, experience motivational displacement and are moved to help". Furthermore, the incidences portray Noddings' (2010c:391) position that "in a caring relation, the carer is first of all attentive to the caredfor and this attention is receptive, that is the carer puts aside her own values and tries to understand the expressed needs of the cared-for". Dr A cautioned and recommended that nobody should respond the same way "if the Lord does not speak to you", confirming Noddings' (2010a) opinion that carers must first think well in order to assess and respond appropriately to the expressed needs of the immediate cared-for. In addition, carers should consider the likely effects of their decisions on the wider web of care and on the caring relationship itself. Clearly, the decisions to stay with the three students whilst having their own children had implications for the family's life. Although Dr A fulfilled the role of a father, he was still their teacher and had to manage that aspect of the relationship as well, thus justifying the view that adults who know they will serve as role models, or likely to be regarded as such, have a special responsibility to show what it means to care by caring. However, their role as model should not overwhelm their actual caring (Noddings, 2010a). Dr A acknowledged that because this dual role was at times compromising, he requested to be excluded from the students' assessments. He also referred to the extra time devoted to teaching by setting up "some sort of a home clinic" to equip them with clinical as well as basic skills, such as time management and effective study techniques.

Of note is that Salazar (2013) argues that a humanising pedagogy correlates with literature on care in education stating that it includes respect, trust, reciprocal relationships, listening, mentoring, high expectation and interest in the student's well-being, which are values that $\operatorname{Dr}$ A models in his practice.

\subsection{The empathy narrative}

In practice, empathy is displayed during positive, supportive interactions and studentcentred classrooms environments (McAllister \& Irvine, 2002). The following narrative by Dr B illustrates such practice. As a start, he mentioned that he grew up as an introvert, focused on academics to define his identity and imagined himself as a surgeon who would appear on the cover of Time Magazine, saying, "it was all about me, all about building a life around me and my performance". However, his life changed when he became a born-again Christian, and he said, "everything changed completely". Eventually he changed from being an introvert to an extrovert, from being timid to being confident and bold. This change developed into a passion to "invest in people, develop them and see them blossom". Unfortunately, there 
was a time when he was also struggling with trauma and deep emotions in his life, but after completing his studies; he left the country to pursue a Master's degree in Medical Education. After completion, he returned to SA and met Dr B, (who was a colleague at that time) who shared the same passion for supporting students.

Dr B's demonstration of empathy was displayed in his conscious approach to developing positive interactions and providing supportive, non-threatening and safe classroom environments for students. He said his desire for such an environment was based on the belief "do unto others as you want them to do unto you". Dr B further referred to the empowerment one receives from people who speak positively into one's life. He notably became very emotional and was almost in tears during the talk, stressing... "so powerful". He also reiterated that he makes an effort to memorise the students' names and have their photos during classes, and said "this freaks them out" as they are not familiar with such practice. In another effort to know the students, he asks them to write a 1500 -word essay about themselves. In the beginning, students are reluctant to write and he instead starts by giving them a 30-minutes lecture about himself, his life, family and barriers around his life, including showing them photos. According to him, this is his way of saying "welcome to my family". He further mentioned that it is a testimony that he is not perfect, demonstrates that lecturers are also human and his attempt to break the myth that lecturers are untouchable. He referred to this approach as "teachers modelling their brokenness". Eventually students write their essays, thus allowing him to know and understand them.

Dr B's narrative affirms the notion that "as we listen to the other, we identify her feelings; we begin to understand what she is going through. As a result, we feel something; when what we feel is close to what the other is expressing, we may say that we are experiencing empathy" (Noddings, 2010b). In addition, Dr B's practice might demystify Hojat et al.'s (2004) claim of the decline in empathy in medical education. Furthermore, his practice demonstrates that empathy can potentially foster openness, attentiveness and positive relationship (McAllister \& Irvine, 2002). Another aspect of his narrative reflects the benefits of sharing short stories, how this practice can build capacity for empathy and an ability to deal with ambiguity in professional settings (Osmond et al., 2012).

\subsection{The love narrative}

According to Cho (2005), Plato and Paulo Freire claimed that love plays an integral part in the educational setting. In quoting Freire, Whitehead (2011:4) wrote "With love, education becomes an open space for thought from which emerges knowledge.... when a teacher and student love one another, they do not have sex, do not merely care for one another, nor do they pass knowledge between each other... If education is to be a space of thought, we must insist with Freire that 'it is impossible to teach without love'". Unfortunately, according to Rowland (2008), the word love is not prominent in educational settings, yet it is not silent. Jansen (2013:1) adds that, "In the voluminous published literature in educational research journals, the word 'love' hardly appears".

In narrating his story on how he incorporates love in his teaching practice, $\mathrm{Dr} C$ explained how he re-defined love for himself and said, "If I say I love somebody I want the best for them". He further stated that when he married his wife he "had to be the best for her in order to love her". Dr C said that he applies this principle to others and in his teaching practice... "if you love them be the best for them". 
Dr C further explained that before he goes to class he prints out students' photos and makes an effort to familiarise himself with their names. When he enters the class, he "purposely" looks at them with the "eyes of love" as if looking at his own children. Interestingly, he mentioned that this practice helps him to have a connection and identify students who seem "stressed" and in a non-intrusive manner finds ways to support them. He related one particular moment when he saw one student who appeared stressed and called her by name during class. The student was shocked, thinking that he is targeting her, as students normally perceive. He decided to "express his love" by praying for her as his own daughter. Amazingly, this student visited his church and as he was the only familiar person, she approached him. Subsequently he put her in contact with one of the women in church who he knew would support her. The woman continued to pray for and with the student, thus providing further support outside the academic environment. In conclusion, $\operatorname{Dr} \mathrm{C}$ said that his story "signifies the importance of caring, humanity, reaching out to students, a symbol that recognises them as real people, the value of love and desiring the best for them".

Dr C's practice affirms that love is at the centre of what teachers do and in moments of happiness, loving and being loved, teachers find meaning in their work and value their lives (Bullough \& Pinnegar, 2009). Unfortunately, higher education institutions neglect this central, but difficult task of learning to love and to live in true peace and harmony with others and nature. This epistemology of love can bridge the divide between intellect and feelings (Palmer \& Zajonc, 2010). Dr C's narrative demonstrates how love can be incorporated in the curriculum and highlights Freire's point that it is impossible to teach without love.

\section{Discussion}

The fundamental purpose of higher education institutions is to develop students holistically as human beings. Regrettably, institutions have tended to focus on cognitive pedagogy and have neglected the humanistic pedagogy, as advocated by Maslow and Rodgers in the 1990s (DeCavalho, 1991). Studies have levelled criticism over the inhumane, impersonal and hostile academic environment and the manner in which it affects students and staff. On the one hand, students continuously experience the academic incivility, humiliation and loss of selfesteem as well as the subsequent poor performance and decreased throughput rates. In medicine particularly, students continue to experience stress. In response, institutions design programmes that unfortunately tend to be ineffective (Tinto, 2009), thus indicating a need to explore other aspects of the academic environment. On the other hand, the members of staff in these institutions are often torn apart as they neglect and/or compromise their humane values.

Astin, Astin and Lindholm, (2011) are of the opinion that institutions have emphasised "outer" aspects such as courses, grades and honours earned, and persistence towards a degree, but neglected "inner" aspects such as values, beliefs, emotional maturity, moral development, spirituality and self-understanding. In particular, Salazar (2013) believes that it is a moral duty and responsibility of educators to understand and enact a humanising pedagogy that is not only grounded in theory and practice, but is shaped by the realities of students and teachers' lives. From a South African perspective, Keet, Zinn and Porteus (2009) assert that a humanising pedagogy is directed by compassion, care, respect and love for students and teachers, and their identities, histories and experiences. The three narratives above are an enactment of a humanistic pedagogy and are based on the realities of the students and the lives of the educators. 
As aligned to Clandinin, Pushor and Orr's (2007) ethical consideration in research, I asked the three participants to read their narratives to verify the representation of their stories and they wrote:

we do not know the impact we have on the lives of others, we do not know why we walk the paths we do, but we need to be aware there are others out there... and then consider we may be influencing them.

This phrase is consistent with Henry Adams' quote "A teacher affects eternity; he can never tell where his influence stops" (Albom, 1997: i). Another comment was "wow, got tears in my eyes again". This show of emotion is important in student-teacher relationships and pedagogical practices (Zembylas, 2011).

\section{Conclusion}

In this article, I reported on the humanistic pedagogical practice of teachers in one medical school's effort to advance and integrate humane values. This article can possibly serve as an example of how institutions and departments can model an aesthetic and humane environment displaying humane values. In addition, perhaps the article provides an answer to alleviating stress among medical students, assist staff members struggling to practice humanistic principles and soften the hearts of the so-called "academic hardliners and elitists". In medicine, humane values are important in providing patient care and should be inculcated in students whilst still on training and be transferred to practice, as affirmed by Haden et al. (2006), who state that a humanistic pedagogy establishes context for the development of interpersonal skills, learning, patient care and making a meaningful contribution to the health profession. In addition, as medical schools strive to teach students to treat patients as individuals and respect their dignity, as stipulated by the General Medical Council (2009) of the United Kingdom, they should also strive to treat students with respect and dignity, love and care, and have empathy for them.

\section{References}

Albom, M. 1997. Tuesdays with Morrie. New York: Doubleday.

Astin, A.W., Astin, H.S. \& Lindholm, J.A. 2011. Cultivating the spirit: How college can enhance students' inner lives. San Francisco: John Wiley \& Sons.

Bartolomé, L. 1994. Beyond the method fetish: Towards a humanizing pedagogy. Harvard Educational Review, 64(2), 173-195. https://doi.org/10.17763/haer.64.2.58q5m5744t325730

Biesta, G.J.J. 1998. Pedagogy without humanism: Foucault and the subject of education. Interchange, 29(1), 1-16. https://doi.org/10.1023/A:1007472819086

Bullough, R.V. Jr. \& Pinnegar, S. 2009. The happiness of teaching (as eudaimonia): Disciplinary knowledge and the threat of performativity. Teachers and Teaching: Theory and Practice, 15(2), 241-256. https://doi.org/10.1080/13540600902875324

Chickering, A.W. \& Gamson, Z.F. 1987. Seven principles for good practice in undergraduate education. Washington Center News, Fall. Available at http://www.lonestar.edu/multimedia/ SevenPrinciples.pdf [Accessed 22 July 2013].

Cho, D. 2005. Lessons of love: Psychoanalysis and teacher-student love. Educational Theory, 55(1), 79-96. https://doi.org/10.1111/j.1741-5446.2005.0006a.x 
Clandinin, D.J., Pushor, D. \& Orr, A.M. 2007. Navigating sites for narrative inquiry. Journal of Teacher Education, 58(1), 21-35. https://doi.org/10.1177/0022487106296218

Clark, C. 2008. Student perspectives on faculty incivility in nurse education: an application of the concept of rankism. Nurse Outlook, 56(1), 4-8. https://doi.org/10.1016/j.outlook.2007.08.003

Cohen, J.J. 2002. Our compact with tomorrow's doctors. Academic Medicine, 77(6), 475-480. https://doi.org/10.1097/00001888-200206000-00002

Condren, S.M., Breitzer, J.G., Payne, A.C., Ellis, A.B., Widstarnd, C.G., Kuech, T.F. \& Lisensky, G.C. 2002. Student-centered nanotechnology-enriched introductory college chemistry courses for engineering students. International Journal of Engineering Education, 18(5), 550-556.

Connelly, F.M. \& Clandinin, D.J. 1990. Stories of experience and narrative inquiry. Educational Researcher, 19(2), 2-14. https://doi.org/10.3102/0013189X019005002

Creswell, J.W., Hanson, W.E., Clark Plano, V.L. \& Morales, A. 2007. Qualitative research designs: selection and implementation. The Counseling Psychologist, 35(2), 236-264. https:// doi.org/10.1177/0011000006287390

DeCarvalho, R.J. 1991. The humanistic paradigm in education. Humanistic Psychology, 19(1), 88-104. https://doi.org/10.1080/08873267.1991.9986754

Derby, L.N., Thomas, N.R. \& Shanafeld, T.D. 2006. Systematic review of depression, anxiety and other indications of psychological distress among U.S. and Canadian medical students. Academic Medicine, 81(4), 354-373. https://doi.org/10.1097/00001888-200604000-00009

Doyle, L.H. \& Doyle, P.M. 2003. Building schools as caring communities: why, what, and why? The Clearing House, 76(5), 259-261. https://doi.org/10.1080/00098650309602016

Edwards, M.T. \& Zimet, C.N. 1976. Problems and concerns among medical students -1975 . Journal of Medical Education, 51(8), 619-625. https://doi.org/10.1097/00001888-197608000-00001

Gaufberg, E.H., Batalden, M., Sands, R. \&. Bell, S.K. 2010. The hidden curriculum: what can we learn from third-year medical student narrative reflections? Academic Medicine, 85(11), 1709-1716. https://doi.org/10.1097/ACM.0b013e3181f57899

General Medical Council. 2009. Tomorrow's doctors. London: GMC. Available at http://www. gmc-uk.org/Tomorrow_s_Doctors_0414.pdf_48905759.pdf [Accessed 5 November 2013].

Haden N.K., Andrieu S.C., Chadwick D.G., Chmar J.E., Cole J.R., George M.C., Glickman G.N., Glover J.F., Goldberg J.S., Hendricson W.D., Meyerowitz C., Neumann L., Pyle M., Tedesco L.A., Valachovic R.W., Weaver R.G., Winder R.L., Young S.K., Kalkwarf K.L. 2006 The dental education environment. Journal of Dental Education, 70(12), 1265-1270.

Harland, T. \& Pickering, N. 2011. Values in higher education teaching. Oxon: Routledge.

Hojat, M., Mangione, S., Nasca, T.J., Rattner, S., Erdmann, J.B., Gonnella, J.S. \& Magee, N. 2004. An empirical study of decline in empathy in medical school. Medical Education, 38(9), 934-941. https://doi.org/10.1111/j.1365-2929.2004.01911.x

Hojat, M., Vergare, M.J., Maxwell, K., Brainard, G., Herrine, K., Isenberg, G.A., Veloski, J.M.S. \& Gonnella, J.S. 2009. The devil is in the third year: a longitudinal study of erosion of empathy in medical school. Academic Medicine, 84(9), 1182-1191. https://doi.org/10.1097/ ACM.0b013e3181b17e55 
Institute for Reconciliation and Social Justice (IRSJ). 2013. The institute embodies the interface between the 'human' project and the 'academic' project. Botho Newsletter of the IRSJ 2. Bloemfontein: University of the Free State.

Jansen, J. 2013. Where there is tough love, there is discipline. Times Live 18 April. Available at http://www.timeslive.co.za/opinion/columnists/2013/04/18/where-there-is-tough-love-thereis-discipline [Accessed 27 September 2013].

Jansen, J., Tabane, R. \& Sehlapelo, H. 2010. 'I must study double now': how students encounter and negotiate academic lives at the University of Pretoria. In Council of Higher Education. Access and throughput in South African higher education: Three case studies. Pretoria: Council on Higher Education.

Keet, A., Zinn, D. \& Porteus, K. 2009. Mutual vulnerability: a key principle in a humanizing pedagogy in post-conflict society. Perspectives in Education, 27(2), 109-119.

Kim, M. \&. Schallert, D.L. 2011. Building a caring relationship between a teacher and student in a teacher preparation program Word-by-Word, Moment-by-Moment. Teaching and Teacher Education, 27(7), 1059-1067. https://doi.org/10.1016/j.tate.2011.05.002

Kleijnen, J., Dolmans, D., Muijtjens, A., Willems, J. \& van Hout, H. 2009. Organisational values in higher education: Perceptions and preferences of staff. Quality in Higher Education, 15(3), 233-249. https://doi.org/10.1080/13538320903343123

Liverpool Hope University. 2009. Faculty of Education - strategic map 2010-11. Available at http://www.actionresearch.net/writings/lhu/LHUFacultyStrategicMap2010-11.pdf [Accessed 24 August 2010].

Lovat, T., Dally, K., Clement, N. \& Toomey, R. 2011. Values pedagogy and student achievement: Contemporary research evidence. London: Springer. https://doi.org/10.1007/978-94-007-1563-9

Lyons, A.W. 2006. Recalling the past, creating a future: Challenges for humanistic research. Humanistic Psychology, 34(1), 13-20. https://doi.org/10.1207/s15473333thp3401_3

McAllister, G. \& Irvine, J.J. 2002. The role of empathy in teaching culturally diverse students: A qualitative study of teachers' beliefs. Journal of Teacher Education, 53(5), 433-443. https:// doi.org/10.1177/002248702237397

Moagi-Jama, M.P. 2009. Designing an academic support and development programme to combat attrition among non-traditional medical undergraduates. Unpublished PhD thesis. Bloemfontein: University of the Free State.

Noddings, N. 2010a. Moral education and caring. Theory and Research in Education, 8(2), 145-151. https://doi.org/10.1177/1477878510368617

Noddings, N. 2010b. Complexity in caring and empathy. Abstracta, Special Issue V, 6-12.

Noddings, N. 2010c. Moral education in the age of globalisation. Education Philosophy Theory, 42(2), 390-396. https://doi.org/10.1111/j.1469-5812.2008.00487.x

Osmond, C., Cumbie, S.A., Dale, M. \& Hosteller, D. 2012. An open letter to our future students in 'narrative and the caring professions'. Journal for Learning through the Arts, 8(1), 1-7.

Ozuah, P.O. 2005. First, there was pedagogy and then came androgogy. Einstein Journal of Biology and Medicine, 21, 83-87. https://doi.org/10.23861/EJBM20052190 
Palmer, P. \& Zajonc, A. 2010. The heart of higher education: A call to renewal. San Francisco: Jossey-Bass.

Peréz, W., Cortés, R.D., Ramos, K. \& Coronado, H. 2010. 'Cursed and blessed': Examining the socioemotional and academic experiences of undocumented Latina and Latino college students. New Directions for Student Services, 131, 35-51. https://doi.org/10.1002/ss.366

Polkinghorne, D.E. 2007. Validity issues in narrative research. Qualitative Inquiry, 13(4), 471486. https://doi.org/10.1177/1077800406297670

Roberts, L.W. 2010. Understanding depression and distress among medical students. Journal of American Medical Association, 304(11), 1231-1233. https://doi.org/10.1001/ jama.2010.1347

Rosenberg, P.P. 1971. Students' perspectives and concerns during their first year in medical school. Journal of Medical Education, 46, 211-218.

Rovai, A.P., Gallien Jr., L.B. \& Wighting, M.J. 2005. Cultural and interpersonal factors affecting African American academic performance in higher education: A review and synthesis of research literature. Journal of Negro Education, 74(4), 359-370.

Rowland, S. 2008. Collegiality and intellectual love. British Journal of Sociology of Education, 29(3), 353-360. https://doi.org/10.1080/01425690801966493

Salazar, M. del C. 2013. A humanizing pedagogy: Reinventing the principles and practice of education as a journey toward liberation. Review of Research in Education, 37, 121-148. https://doi.org/10.3102/0091732X12464032

Teven, I. \& McCroskey, A. 1997. The relationship of perceived teacher caring with student learning and teacher evaluation. Communication Education, 46(1), 1-9. https://doi. org/10.1080/03634529709379069

Thomas, L. 2002. Student retention in higher education: the role of institutional habitus. Journal of Education Policy, 17(4), 423-442. https://doi.org/10.1080/02680930210140257

University of the Free State (UFS). 2013. Integrated report. Bloemfontein: University of the Free State. Retrieved from http://wwwufs.ac.za/docs/default-source/all documents/integratedreportufs-2013 on 23 September 2014.

Veerapen, K. \& McAleer, S. 2010. Students' perceptions of the learning environment in a distributed medical programme. Medical Education Online, 15: 51-68. https://doi.org/10.3402/ meo.v15i0.5168

Veugelers, W. 2011. A humanistic perspective on moral development and citizenship education. In W. Veugelers, (Ed.). Education and humanism linking autonomy and humanity. Rotterdam: Sense.

Whitehead, J. 2011. Accounting for ourselves in our living educational theories. Notes for a presentation for the foundation hour at Liverpool Hope University, 12 February 2011. Available at http://www.actionresearch.net/writings/jack/jwlhufoundation120111.pdf [Accessed 18 August 2013].

Whitman, N.A., Spendlove, D.C. \& Clarke, C.H. 1984. Students' stress: Effects and solutions. ASHE-ERIC Higher Education Report No 1. Washington DC: The George Washington University, School of Education and Human Development. 
Wilcox, J.R. \& Ebbs, S.L. 1992. The leadership compass: Values and ethics in higher education. ASHE-ERIC Higher Education Report No 1. Washington DC: The George Washington University, School of Education and Human Development.

Zembylas M. 2011. Teaching and teacher emotions: a post-structural perspective. In: Day, C. \& Chi-Kin Lee, J. (Eds.). New understandings of teacher's work: Emotions and educational change. New York: Springer. https://doi.org/10.1007/978-94-007-0545-6_3 